This is an Open Access article, distributed under the terms of the Creative Commons Attribution licence (http://creativecommons.org/licenses/by/4.0/), which permits unrestricted reuse, distribution, and reproduction in any medium, provided the original work is properly cited.

\title{
Modern Colonialism, Eurocentrism and Historical Archaeology: Some Engendered Thoughts
}

\author{
Sandra Montón-Subías ${ }^{1}$ (i) and Almudena Hernando ${ }^{2}$ \\ ${ }^{1}$ Departament d'Humanitats, Universitat Pompeu Fabra, Barcelona, Spain; ICREA, \\ Barcelona, Spain \\ ${ }^{2}$ Departamento de Prehistoria, Universidad Complutense, Madrid, Spain
}

In this article, we would like to share some thoughts related to the values and principles implemented by archaeologists when bringing 'the other' into focus. We situate our reflections within the archaeology of modern colonialism, and revisit some aspects related to one of the most vibrant issues in historical archaeology: Eurocentrism. It is our understanding that 'de-Eurocentring' the discipline not only requires introducing the disenfranchised as new agents, but also questioning the most profound logics by which narratives of the past have been written. We focus on the idea of history as change, and on the notion of social continuity from a feminist standpoint. We have noticed that certain accounts of colonial situations, even those with the opposite intention, may project the prevailing Western male way of being while trying to explain past social and personal dynamics, thus blurring ontological diversity and unwittingly reinforcing the Eurocentrism we are trying to avoid.

Keywords: historical archaeology, modern colonialism, Eurocentrism, feminist archaeology, change and continuity, maintenance activities

\section{INTRODUCTION}

'Quand on aborde un problème aussi important que l'inventaire des possibilités de compréhension de deux peuples différents, on doit redoubler d'attention.' (Fanon, 1952: 67) ${ }^{1}$

In their critique of Eurocentrism, Latin American decolonial thinkers situate the origins of the first true World Order in the modern conquest and colonization of the Americas (e.g. Wallerstein, 1974;

1 When one approaches a problem as important as that of an inventory of the possibilities for understanding between two different peoples, one should be doubly careful' (translation in Fanon, 1986: 84).
Wolf, 1982; Quijano \& Wallerstein, 1992; Dussel, 1995, 2000; Lander, 2000; Castro Gómez \& Grosfoguel, 2007; Mignolo, 2008; and, for related ideas, Marks, 2002; Parker, 2010; Gruzinski, 2012). Profound changes of all types followed. These were not only changes in a known world that merely altered some of its traits' but 'changes in the world as such' (Quijano, 2000: 547).

This new colonial world encompassed the emergence of Eurocentrism as a new rationale, and eventually constructed a Eurocentric self-legitimating historical discourse. Following decolonial authors (e.g. Lander, 2000: 14; Quijano, 2000), we 
understand that this new rationale organized all peoples of the world, past and present, into a single universal narrative, with Europe representing both the geographical centre and the summit of all temporal movement. This narrative was fully developed in the nineteenth century (Amin, 1988; Blaut, 1993, 2000; Wallerstein, 2006; Álvarez-Uría, 2015), when history and archaeology, as institutionalized academic disciplines, replaced myth as the discourse to explain the past (Hernando, 2012b). New understandings of space, time, and human agency, and, basically, the glorification of history as change took the stage (Quijano, 2000: 547). Archaeology and history thus shared fundamental conceptual foundations: the assumption that change was the axis through which to think the world, the perception of time as a linear trajectory, and the idea of space as a bi-dimensional parameter that could be expanded endlessly. This particular, and situated, way of understanding the world, which has dominated the social order since the nineteenth century, was considered to be universal and inherent to any human reading of the world. But it was not universal, as we will discuss in this article.

In the 1960s, modern colonial processes were used to demarcate historical archaeology, a subfield of the discipline that originally emerged in the United States and was soon defined as the archaeology of the spread of European cultures throughout the world since the fifteenth century, and their impact on and interaction with the cultures of indigenous peoples' (Deetz, 1996 [1977]: 5). ${ }^{2}$ Historical archaeologists soon expressed concerns against

2 We are well aware that historical archaeology is a controversial term and that there has been an energetic debate about its narrow versus wide chronological adoption. Here, we use the term to refer to the study of all processes connected to the European expansion, conquest, and colonization that began in the Late Middle Ages, and that have moulded the world to its present
Eurocentrism, and strong efforts have been made ever since to identify, scrutinize, and demolish Eurocentrism in our discipline (for a discussion, see Orser, 2012). Here, we would like to deepen this critique. It is our contention that more attention needs to be paid to the logics underlying the writing of history. Otherwise, we may end up strengthening the most profound rationale behind traditional Eurocentric narratives, hence curbing our ability to appreciate cultural difference and idiosyncrasy in the past.

We focus on the idea of history as change and on the notion of social continuity from a feminist standpoint. Most specifically, we stress: 1) that a positive appraisal of change is always associated with individuality; 2) that individuality runs parallel to the emergence and increase of social hierarchization and technological development; 3) that individuality is a type of personhood that, in Europe, has characterized most men since the Early Modern period; 4) that persons in non-hierarchical societies appreciate stability and continuity more than change; 5) that while human history has been a combination of continuity and the search for change, history as a discourse has mainly emphasized change; 6) that, therefore, the logics behind the historical and archaeological discourse is an expression of the modern hegemonic individualized masculinity (sensu Connell \& Messerschmidt, 2005); and 7) that the perception of change typical of Western male individuality has been wrongly projected onto the interpretation of the past. Consequently, we understand that Eurocentrism was/is not so much the imposition of the European understanding of the world, but of a specific European understanding of the world: the male or

shape (Leone \& Potter, 1988; Orser, 1996; Little, 2007). 
patriarchal one operating in Europe at the time of the continent's worldwide expansion.

\section{Some Thoughts on Eurocentrism and Historical Archaeology}

Since Wolf's (1982) Europe and the People Without History, and partly as a reaction to burning critiques of Eurocentrism, many historical archaeologists have considered it an important goal to give voice to the voiceless and, thus, rescue from oblivion all those unrecalled in traditional historical narratives (e.g. Funari, 1991; Orser, 1996; Hall, 1999; Kelly, 2003; Leone, 2011; Escribano-Ruiz, 2016). At about the same time as this goal permeated historical archaeology, Gayatri Chakravorty Spivak (1988), a feminist and postcolonial scholar scrutinizing pervasive Eurocentrism in postcolonial discourse, was already questioning whether it was possible for the subaltern to speak, making reference to the most Western embedded structures of thought in the production of knowledge. Coloniality, a term used later by decolonial authors drawing on Frantz Fanon's legacy (e.g. Quijano, 1992; Lander, 2000; contributions in Julia Suárez-Krabbe et al., 2009), also refers to colonialism within today's production of knowledge, and to the imposition of knowledge systems generated by Europeans through such disciplines as anthropology, history, and archaeology (see also Chakrabarty, 1992). Fanon himself (1952: 120) mentions as a glaring example how schoolchildren in Martinique were taught about the Gauls being their ancestors, which promoted an immediate identification with European subjectivities and worldviews.

Debunking Eurocentrism necessarily encompasses debunking the coloniality of knowledge, which implies interrogating dominant values behind the construction of historical and archaeological explanations of the past. Eurocentrism (and androcentrism) has found here one of its most impregnable hideouts, to the point that it often goes unnoticed. An anecdote from a few years ago will illustrate this point (see Montón-Subías \& Abejez, 2015: 25). In the session 'Entangled Colonialism: Changes in Material Culture and Space in the Late Medieval through to the Modern Period' that took place at the 2012 European Association of Archaeologists Annual Meeting, Richard Ciolek-Torello explained that some Native American subsistence strategies in southern California had been profoundly modified after the implantation of the Spanish Catholic missions. In this way, he emphasized, some social dynamics that had remained relatively stable had been truncated. In the Q\&A session that followed, one of the attendees considered this vision of Native Americans as Eurocentric. According to her, in thinking that it had been the missionaries who had first brought change to the area, he was reinforcing an image of native populations as backward, by denying the indigenous people the same capacity and desire for change as the Spaniards.

Although different authors have been critical about the fact that change has been valued in an overly positive way in archaeology (e.g. Panich, 2013; GonzálezRuibal, 2014; Lightfoot, 2015), it is also true that many archaeologists still consider that 'giving voice to the voiceless' requires attributing them the same attitude towards change and the same degree of individuality that characterize individuals in the present (e.g. Sampson, 1988; Ewing, 1990; Cohen, 1994; Knapp \& Meskell, 1997; Sökefeld, 1999; Moore, 2000; Knapp \& Van Dommelen, 2008; Machin, 2009; but see Thomas, 2004, for a critique).

In the wake of concerns about Eurocentrism, claims about the stability of 
non-European societies have come to be considered Eurocentric (and politically incorrect), and it is easy to understand why. Lack of change or a slower pace of change-interpreted as a lack of progress-was one of the main features Eurocentric thought once emphasized to describe non-European societies and depict them as inferior (e.g. Kant, 1784). Therefore, one might expect reactions to Eurocentrism to have included deconstructing the belief that equated changelessness with backwardness. Nevertheless, this has not been the case, and reactions to Eurocentrism have very often shared with it the idea that the European pattern of change is universal.

Besides sharing with others (e.g. Thomas, 2004; Olivier, 2013; GonzálezRuibal, 2014) a critical attitude to this idea, we want to take a step further. To us, projecting the pattern of change applauded by hegemonic Western history onto any human group is not only Eurocentric but also androcentric. Embedded in this pattern are the values characterizing the construction of the hegemonic male self in European culture at the time of its modern colonial worldwide expansion. This male self was constructed through an increasing emphasis on individuality and reason (Weintraub, 1978; Lloyd, 1984; Morris, 1987; Seidler, 1993), a linear perception of time and a positive appraisal of change (Seidler, 1989; Hernando, 2012a). It is precisely on the basis of such universalization-the identification of the typical European male identity since Early Modernity as the only possible type of identity for all human beings (Hernando, 2012a) — that the idea that past peoples might have had other types of identities causes a shock among some archaeologists, as the anecdote told above exemplifies. And it is precisely because of current ingrained Eurocentrism that claiming stability (and other ways of being) for native populations can be misjudged as offensive, and as Eurocentric. In fact, the truly Eurocentric stance is not being able to recognize the possibility that other societies might prefer stability to change, and their ability to constitute ways of being a person that-although equally valid-are radically different from those existing in Europe or the West.

In order to promote alternative and more inclusive narratives, we must question the way historical and archaeological accounts have been created and how they have conveyed biased Eurocentric understandings of the past. It is, thus, not only important to focus on bringing attention to those who have been ignored, but also to highlight the mechanisms and motives underlying the construction of such Eurocentric understandings. We consider an alliance with feminist thought to be fundamental to this task. Although not all androcentrism is Eurocentric, Eurocentrism is always androcentric. It is an expression of the rationale and gender identity of those in command of the world, mostly men, both in the past and in the present (Millet, 1972).

From a feminist standpoint, Eurocentrism would be a self-interested and partisan construct about the European historical trajectory. Change, individuality, reason, and, with them, power, self-control, violence (exercised as a means to obtain, wield, or regain power), technical progress, or economic growth have been considered the universal goals of all human beings ever since the Enlightenment (see Seidler, 1989, 1993; Connell, 1995; Connell \& Messerschmidt, 2005), which explains why these same values have been used by mainstream archaeological and historical discourses to describe other societies (Hernando, 2012b). But, in Europe, such values only became generalized as a way to construct men's identities in the seventeenth century. 'If we think that growth and change are more advanced than 
stability or continuity', Francesca Bray argued in 1997, 'it is because that is how our modern Western world was made [...] But other worlds were made in other ways' (Bray, 1997: 12). We would go further and say that even our own world was made in other ways by integrating components such as human bonds, community, continuity, emotions, or the search for protection among others. However, only the first group of these components was recognized by social discourse and mainstream science (see Seidler, 1993; Hernando, 2012b; Fowler, 2016).

\section{Archaeology and the IDEA of Change}

Archaeology and history are intrinsically linked to the idea of change as they are discourses about our origins that were fully constructed in the nineteenth century to replace myth, which was characterized in turn by the absence of time and change. Since the Western world (as well as others) is the result of changes over time, researching change in these disciplines is not in itself problematic. The problem arises when these accounts of the past underscore the importance of social dynamics whose function was to promote continuity, stability, security, bonds, and belonging, as these dynamics play a fundamental role in the groups' ability to generate changes without creating feelings of ontological anxiety or life disorientation (Giddens, 1991: 35-47). In this respect, mainstream archaeology and history have constituted 'partial' discourses about the dynamics that explain our past, and have reflected only one side of human behaviours: those acknowledged by the men who constructed that very historical discourse.

Regarding the historical archaeology of culture contact and colonialism, Kent Lightfoot (2015: 9218) has noticed how categories dealing with contact-from the much-reviled acculturation to more recent constructs such as hybridity, creolization, or ethnogenesis-have focused mainly on the dynamics of change, although he has also drawn attention to the 'growing interest in the investigation of cultural persistence' (2015: 9221). Works by several authors (including Lightfoot's in 1995, and Lightfoot et al., 1998) have considered both types of dynamics, trying to increase awareness of the fact that societies are not only made of changes but also of continuities (e.g. Silliman, 2005, 2009; Rodríguez-Alegría, 2008, 2014; Ferris 2009; Mitchell \& Scheiber, 2010; Hernández, 2012; Stahl, 2012; GonzálezRuibal, 2013, 2014; Panich, 2013; Wright \& Ricardi 2014; Flexner et al., 2015).

However, it is feminist archaeology, with its critique to androcentrism, that has been reflecting the longest on the profound reasons why master narratives have ignored continuity, explaining why it needs to be unveiled and theorized, and showing its social value. We have discussed elsewhere (Hernando, 2008, 2012a) why the idea of history as change cannot be separated from the emergence of the modern male subjectivity in Europe, and thus why emphasis on social change, to the detriment of social continuity, has been at the core of archaeology and history as academic disciplines. Let us make a short digression to clarify this point.

This digression relates to the (pre) historic roots of Western gender inequality and the interplay between individuality and relationality in the construction of personhood throughout European history. Although very recent non-feminist studies are beginning to acknowledge the importance of relational identity in analyses of the past (e.g. Sedikides \& Brewer, 2015; Fowler, 2016), from a feminist standpoint the stress has been placed on understanding the different ways in which the 
interaction between relational and individualized identity has differentially affected male and female selves throughout history (Hernando, 2012a, 2012b). Unlike other studies, these works emphasize the interplay between conscious and unconscious identities throughout the development of the masculine self/masculine individuality in European history, and propose different trajectories in the development of men's and women's identities in the Western world. One critical point is that relational identity is indispensable to generate ontological security and is, thus, always present in all types of self, although it is not always acknowledged.

Unlike other approaches, we have argued that, in our most remote past, both men and women must have been characterized by relationality and not by individuality as there were neither different positions of power nor work specialization (Hernando, 2012a). When features of individuality began to appear as a counterpart of increasing power and technological control sustained by some men, relational ones did not disappear in them, but began to be 'performed' unconsciously, in an unacknowledged way instead (essentially through normative heterosexuality and social groups of male peers). Women, whose individualization men prevented until Late Modernity in order to guarantee their own 'relational' bonds, became the necessary complement for them. In this way, men were only conscious of their individualized identity, while performing their relational one through subordinated women (who, in not being individualized, did not develop a desire or ability for change or power). Men and women then followed different identity pathways: increasing individuality (mixed with unacknowledged relationality) in men, and only relationality in women until Late Modernity (Hernando, 2012a, 2012b; see also Lloyd, 1984; Seidler, 1993).
Positive appraisals of change are inextricably linked to individuality as a mode of self-identity, and to the increase of technological control over the world and the subsequent feeling of power before it. Individuality only appears when differentiated positions of power exist within groups and when persons begin to feel different from each other, progressively taking on the position of agents of their own destinies. At this point, their ontological security no longer stems from the protection of a sacred instance and bonds with the group, but from their own ability to increase (and thus change) their control over the environment. In this way, the greater the level of specialized functions and hierarchical positions, the higher the level of individuality of those in such positions will be, and the more their security will rely on their own ability to change.

There is consensus among scholars who have studied individuality that one of its defining features is reflexivity, a strong awareness of oneself as a differentiated entity and a sense of coherence as guiding self-transformation in the course of one's life (Weintraub, 1978: 95; Veyne, 1987: 7; Giddens, 1991: 20, 52). Individuality, change, technological development, and a rational understanding of the world all characterize the process of growing division of functions and differentiation of power positions wherever such a process takes place, at any time in history. But it was in Europe that it reached its peak in Early Modernity, and where it was experienced mainly by men until late modern times. The more individualized men became, the more importance they gave to change, individual agency, or technological development, and the more 'dependent' they became on women to act relationality. In other words, the more importance men gave to change, individual agency, and technological development, the more patriarchal their relation with women became. 
For all these reasons, the dominant historical discourse has been mostly an expression of male perspectives on reality. Therefore, the idea of history as change, so enmeshed in our perception of history, is in itself androcentric and historical, and far from universal.

\section{The Social Value of Continuity}

In their critique of androcentrism, feminist scholars, including archaeologists, have drawn attention to the fact that discourses about the past have mainly commended values, attitudes, and capacities associated to dominant Western male identity; a type of logic that conceals and rejects values associated to the construction of traditional female gender identity such as relationality, interdependence and social bonding, emotion, care, stability, durability, continuity, and recurrence (e.g. Seidler, 1989, 1993; Connell \& Messerschmidt, 2005; González Marcén et al., 2008; MontónSubías, 2010; Montón-Subías \& Lozano, 2012; Hernando, 2012a, 2012b). It has been shown that, while space and time are structural in the making of selves, they can be experienced in substantially different ways by different human groups (Giddens, 1991: 37), and this difference also holds true for genders and people in different positions of power within the same group (González Marcén \& Picazo, 1997; Damm, 2000; Hernando, 2002). ${ }^{3}$

The less technological control characterizes human groups, the more they pursue stability and reject change, the more importance is given to interdependence and emotional bonds to feel

3 Although, from different perspectives, other scholars have also discussed time as a cultural notion that might have been differently perceived in the past (e.g. Leone, 1978; Fabian, 1983; Bailey, 1987; Shanks \& Tilley, 1987; Gosden \& Lock, 1998; Lucas, 2005; Goody, 2006; Olivier, 2008, 2013; Verdesio, 2013; GonzálezRuibal, 2014). ontological security, the more cyclical their concept of time is, and the greater the attachment they feel to their space, as stability will constitute the desired goal (Munn, 1992; Elias, 1993; Gell, 1996). By the same logic, it can also be argued that, within a given group, those people who carry out more specialized tasks (which are more closely associated with change) will have more linear visions of time and will attribute less importance to their links with space and with other members of the group than those who do not carry out these specialized tasks. In general terms, women tend to be among the latter in most historical trajectories. So, the values and attitudes of colonizers, travellers, and explorers in the periods studied by historical archaeology reflected those of the most individualized men of their time, but not those of many other men or women in their own society, nor those of the people they were colonizing, visiting, or exploring.

Feminist studies have, therefore, focused on spheres of practice which mainstream archaeology had neglected, as they were not the expression of changes over time or rapid technological advance. Among these are 'maintenance activities', mainly carried out by women in most societies. Initially catalysed by feminist challenges to unveil sexist bias in the archaeological discipline (Bertelsen et al., 1987), and closely linked to developments in feminist gender and feminist household archaeology (Conkey \& Gero, 1991; Tringham, 1991; Hendon, 1996), the concept of maintenance activities has been used to underscore the structural and foregrounding nature of a set of practices which are fundamentally necessary to guarantee the stability and continuity of life in any human group (Picazo, 1997; González Marcén et al., 2008). They include, grosso modo, all activities related to feeding and food processing, basic clothing and weaving, care giving, raising and 
socializing children, and fitting out and organizing related spaces. These activities are fundamental in regulating and stabilizing social life, and in guaranteeing the group's cohesion through the strengthening of its basic bonds (e.g. Dommasnes, 2008; Gifford-Gonzalez, 2008; Gilchrist, 2008; González Marcén et al., 2008; Sánchez Romero, 2008).

Maintenance activities appear in varying forms and are organized in different ways from one culture to another, but invariably play a structural role in all of them. They are carried out on a day to day basis (although they do not take up daily life completely) and are inseparable from the relational social tissue they generate and within which they unfold. Grouping them all under the same denomination has highlighted the collective function shared by them all, which would otherwise remain clouded.

Grouping these activities has also served the purpose of tracing the development of a common set of social values they all embody (Hernando, 2008; MontónSubías, 2010; Montón-Subías \& Lozano, 2012). By underlining the value of links and social bonding, of emotional skills, and of maintaining relationships and care as fundamental pillars of social life, researchers have raised awareness of the importance of relationality, interdependence, stability, continuity, and recurrence in the course of history. Already in the 1990s, a work on Bronze Age Iberia called for a focus 'on the role of stability as an alternative historical perspective, rather than emphasizing the dynamics of change' (Colomer et al., 1998: 53). The article not only brought continuity to the fore, but also criticized the tendency to regard past social stability as stagnant and backward, instead of considering it a resilient, sustainable, and successful strategy.

Needless to say, maintenance activities have also changed throughout history, and both archaeology and history have contributed many examples in different periods and spaces (e.g. Cowan, 1989; Brumfiel, 1991; Hastorf, 1991; Brumfiel \& Robin, 2008; Meyers, 2008; Sánchez Romero \& Aranda, 2008; Tarble de Scaramelli \& Scaramelli, 2012). However, under normal circumstances, the pace at which they change is incomparably slower than that of other tasks, since their ultimate function is to guarantee the reiteration and recurrence of the group's activities, and/or to channel any changes in the latter into new reiteration and recurrence patterns or, in other words, into new ways of everyday life management (for a wider discussion, see González Marcén et al., 2008).

We consider the study of maintenance activities crucial to understand such colonial situations as those studied by historical archaeology. Such is the perspective we are applying in the framework of a research project related to the incorporation of Guam and the Mariana Islands into the colonial network of the Spanish Empire in the seventeenth century (Montón-Subías et al., forthcoming). While a more detailed account of this case lies beyond the scope of this article, some of the project's more general and preliminary conclusions exemplify the topic well. In Guam, as in many other places where colonization was part of a 'civilizing' project (sensu Fanon, 1952), the implementation of the very colonial enterprise on the ground brought relevant transformations in the sphere of maintenance activities. This, we would like to insist, was due to their key role in channelling changes in new ways of managing everyday life.

In the case of Guam, it seems clear that, almost since the first moment of permanent colonization in 1668 , maintenance activities were the target of colonial policies. From the concentration of the population and the re-structuration of living spaces in reducciones to children's 
socialization in Jesuit seminaries, through food systems, dress, kinship, healing practices, and sexuality, Jesuit missionaries aimed to dismantle traditional Chamorro lifeways, which were mainly organized through maintenance activities (Moral, 2016; Montón-Subías et al., forthcoming). Thus, while for Jesuit missionaries the colonization of the Marianas Islands was a mainly political-and-religious enterprise, for natives on the islands it was the deep structure of the world and the bonds that connect humans to it that were at stake.

Although the Guam example is but one of the many examples making up the heterogeneous colonial matrix of Early Modernity, we believe that it clearly illustrates the paramount importance of maintenance activities within it. In situations of de-structuration and forcible change, such as those characterizing many colonial processes, it is particularly important to study those dynamics which seek continuity and stability. It is, therefore, necessary to understand how maintenance activities make possible the continuity of both local populations and those arriving throughout the colony's history, as well as the viability (or not) of the very colonial projects.

It would be of great interest to engage in a comparative reading of maintenance activities in colonial situations. Fortunately, several archaeological works have documented one or more of these activities in such situations. The list, which could begin with Deagan's works at St Augustine (1983), is too long to reproduce here (but see Voss, 2008, for a discussion of many of the resulting publications in the Americas, and Fogle et al., 2015, for a recent publication). However, a comparative study has not yet been carried out, and this would be very helpful to better illustrate the way in which dynamics of stability, recurrence, and continuity were involved in this first world globalization. By making them manifest, dynamics different from those of hegemonic masculinity are addressed, and a more comprehensive world history can be constructed.

\section{Some Final Thoughts}

Eurocentrism is such an embedded part of the Western rationale that only through constant interrogation and inquiry will we be able to denude its multiple layers (sensu Lander, 2000: 7). Here, we have argued that one of these layers remains in assumptions ingrained in the background that configure the most intimate discursive structure we use to interpret the past. These deep assumptions identify historical dynamics with the logic characterizing modern male identity, eliding the much more complex dynamics structuring society.

As archaeologists, and particularly as archaeologists dealing with the effects of early European expansion and colonization, we have a special responsibility. We are interpreting colonial situations that encompass contact and domination over people with very different inner cultural logics and, thus, with different, even contrasting, understandings of the self and worldviews, and with historical dynamics guided by values and forces which differed from those of the West. We, therefore, have the responsibility of trying to understand these 'other' in their 'otherness', and not as part of 'the same' (ourselves) (Dussel, 1995: 12). For this reason, paraphrasing Fanon quoted at the beginning of this article, we must be doubly careful. Otherwise, we may interpret 'other people's' historical dynamics from the same parameters and values constructed by Western history. Far from being universal, as our discussion shows, those parameters and values are historically and geopolitically contextualized, and aimed at legitimizing-let us reiterate-only a biased European discourse. In our own Eurocentric projection of values, we do 
not only reaffirm Europe and the present (Olivier, 2013), but the patriarchal order intrinsic to its social discourse. We must stress that we are by no means arguing that all groups outside Western modernity regard change in a negative way. On the contrary, we hope to have made it clear that the extent to which change is positively appraised depends on the group's degree of social hierarchization and technological control over their life circumstances. Consequently, it is very important to recognize that the positive values we place on the idea of change rest on a certain historical genealogy, and not on any 'moral' grounding (in other words, that it is neither better nor worse to have change).

Furthermore, the positive appraisal of change and the ensuing perception of time espoused by archaeologists in the present are different, for both the colonized groups we study and for the many people in Europe at the time. In this respect, two more points should be made: 1) The fact that European societies generally presented higher levels of technological control and higher differences in social power caused the process itself to impose 'accelerated' paces of change and perceptions of time onto those of the subjugated peoples (see Suzman, 2004, for a related example in contemporary Africa); and 2) that European colonizers brought with them higher levels of gender inequality than had previously characterized subaltern populations (e.g. Allen, 1992; Hughes \& Hughes, 1997; Oyewumi, 1997; Lugones, 2008; Paredes, 2008; Segato, 2015).

We also hope to have made it clear that claiming the importance of stability and continuity in the history of humankind should not be confused with proposing stagnation or backwardness, precisely the image of native societies that Eurocentrism promoted (see, for instance, Adas, 1989). The Eurocentric imagination considered the 'other' a-historical because their ways of being in the world followed patterns that were different from those extolled by history as a discipline. However, reading the 'absence' (or a slower pace) of change as a disadvantage, or ignoring dynamics of permanence and continuity, is also a product of Eurocentrism and of its androcentric bias. Incorporating the Other into narratives of the past does not mean ascribing to them Western historicities or the parameters that have been used in their construction, as has often stemmed from Eurocentric fear (e.g. critiques by Ewing, 1990; Cohen, 1994, or Moore, 2000). It means recognizing and acknowledging other forms of historicity and incorporating their background values and principles into the writing of history. In our view, this is one of the main potentials of historical archaeology (and of archaeology in general). In addition, and importantly, feminist works such as those presented here attempt to raise awareness of the fact that the type of historicity privileged by mainstream discourse is far from universal, even within the very geographical context of the West. Here too, 'internal others' challenge the supremacy of history as change. Therefore, de-colonizing history not only implies bringing new agents and geographies to world history, but also new ways of understanding ourselves, making visible the features associated with relationality that male individuality has concealed and, therefore, making possible its recognition in 'the other'. Granted, this is a great responsibility, but it is also a great opportunity to regain ontological heterogeneity and to understand the true and most profound implications of colonial contacts.

\section{ACKNOWLEDgments}

This article was written with the support of the Spanish Ministry of Economy and 
Competitiveness under Grant HAR201677564-C2-1-P and Grant HAR201677564-C2-2-P. Heartfelt thanks go to Enrique Moral de Eusebio for his helpful comments and suggestions. For the same reasons, we would also like to thank Catherine Frieman and the two anonymous referees that peer-reviewed our first manuscript. Thanks as well to Pedro Pablo Fermin Maguire and Madeleine Hummler for making our English much better.

\section{REFERENCES}

Adas, M. 1989. Machines as the Measure of Men: Science, Technology, and Ideologies of Western Dominance. Ithaca and London: Cornell University Press.

Allen, P.G. 1992. The Sacred Hoop: Recovering the Feminine in American Indian Traditions. Boston (MA): Beacon Press.

Álvarez-Uría, F. 2015. El reconocimiento de la humanidad. España, Portugal y América Latina en la génesis de la modernidad. Madrid: Morata.

Amin, S. 1988. L'Eurocentrisme. Critique d'une idéologie. Paris: Anthropos.

Bailey, G. 1987. Breaking the Time Barrier. Archaeological Review from Cambridge, 6: 5-20.

Bertelsen, R., Lillehammer, A. \& Næss, J. R. eds. 1987. Were They All Men? An Examination of Sex Roles in Prebistoric Society. Stavenger: Arkeologist museum i Stavenger.

Blaut, J.M. 1993. The Colonizer's Model of the World: Geographical Diffusionism and Eurocentric History. New York \& London: The Guilford Press.

Blaut, J.M. 2000. Eight Eurocentric Historians. New York \& London: The Guilford Press.

Bray, F. 1997. Technology and Gender: Fabrics of Power in Late Imperial China. Berkeley (CA): University of California Press.

Brumfiel, E. 1991. Weaving and Cooking: Women's Production in Aztec Mexico. In: J. Gero \& M. Conkey, eds. Engendering Archaeology. Women and Prehistory. Oxford: Basil Blackwell, pp. 224-51.
Brumfiel, E. \& Robin, C. 2008. Gender, Households, and Society: An Introduction. In: C. Robin \& E. Brumfiel, eds. Gender, Households, and Society: Unraveling the Threads of the Past and the Present (Archaeological Papers of the American Anthropological Association 18). Malden (MA): Blackwell, pp. 1-16.

Castro Gómez, S. \& Grosfoguel, S. 2007. Prólogo. Giro decolonial, teoría crítica y pensamiento heterárquico. In: S. Castro Gómez \& S. Grosfoguel, eds. El giro decolonial. Reflexiones para una diversidad epistémica más allá del capitalismo global. Bogotá: Siglo del Hombre Editores, pp. 9-23.

Chakrabarty, D. 1992. Postcoloniality and the Artifice of History: Who Speaks for 'Indian' Pasts? Representations, 37: 1-26.

Cohen, A.P. 1994. Self-Consciousness: An Alternative Anthropology of Identity. London: Routledge.

Colomer, L., González Marcén, P. \& Montón-Subías, S. 1998. Maintenance Activities, Technological Knowledge and Consumption Patterns: A View of Northeast Iberia (2000-500 Cal BC). Journal of Mediterranean Archaeology, 11: 53-80.

Conkey, M. \& Gero, J. 1991. Tensions, Pluralities, and Engendering Archaeology: An Introduction to Women and Prehistory. In: J. Gero \& M. Conkey, eds. Engendering Archaeology. Women and Prehistory. Oxford: Basil Blackwell, pp. 3-30.

Connell, R.W. 1995. Masculinities. Berkeley (CA): University of California Press.

Connell, R.W. \& Messerschmidt, J.W. 2005. Hegemonic Masculinity: Rethinking the Concept. Gender and Society, 19: 829-59.

Cowan, R.S. 1989. More Work for the Mother: The Ironies of Household Technology from the Open Hearth to the Microwave. London: Free Association Books.

Damm, C. 2000. Time, Gender, and Production: A Critical Evaluation of Archaeological Time Concepts. In: M. Donald \& L. Hurcombe, eds. Gender and Material Culture in Archaeological Perspective. New York: Palgrave Macmillan, pp. 110-22.

Deagan, K. 1983. Spanish St Augustine: The Archaeology of a Colonial Creole Community. New York: Academic Press.

Deetz, J. 1996 (1977). In Small Things Forgotten: The Archaeology of Early American Life (revised ed). New York: Anchor Books. 
Dommasness, L.H. 2008. 'On a whirling wheel their hearts were made': Women between Ideology and Life in the Nordic Past. In: S. Montón-Subías \& M. Sánchez Romero, eds. Engendering Social Dynamics: The Archaeology of Maintenance Activities (BAR International Series 1862). Oxford: Archaeopress, pp. 87-95.

Dussel, E. 2000. Europa, Modernidad y Eurocentrismo. La colonialidad del saber: eurocentrismo y ciencias sociales. In: E. Lander, ed. Perspectivas lationoamericanas. Buenos Aires: CLASCO, pp. 41-53.

Dussel, R. 1995. The Invention of the Americas: Eclipse of 'the Other' and the Myth of Modernity. New York: Continuum.

Elias, N. 1993. Time: An Essay. London: Basil Blackwell.

Escribano-Ruiz, S. 2016. Desde una arqueología inclusiva, por un pasado mejor. Un ensayo epistemológico y axiológico. Complutum, 27: 21-30.

Ewing, K.P. 1990. The Illusion of Wholeness: Culture, Self, and the Experience of Inconsistency. Ethos, 18: 251-78.

Fabian, J. 1983. Time and the Other: How Anthropology Makes its Object. New York: Columbia University Press.

Fanon, F. 1952. Peau noire masques blancs. Paris: Seuil.

Fanon, F. 1986. Black Skin, White Masks. London: Pluto Press.

Ferris, N. 2009. The Archaeology of NativeLived Colonialism: Challenging History in the Great Lakes. Tucson (AZ): University of Arizona Press.

Flexner, J.L., Willie, E., Lorey, A.Z., Alderson, H., Williams, R. \& Ieru, S. 2015. Iarisi's Domain: Historical Archaeology of a Melanesian Village, Tanna Island, Vanuatu. Journal of Island and Coastal Archaeology, 11: 26-49.

Fogle, K.R., Nyman, J.A. \& Beaudry, M.C. eds. 2015. Beyond the Walls: New Perspectives on the Archaeology of Historical Households. Gainesville (FL): University Press of Florida.

Fowler, C. 2016. Relational Personhood Revisited. Cambridge Archaeological Journal, 26: 397-412.

Funari, P.P. 1991. A arqueologia e a cultura africanas nas Américas. Estudios Iberoamericanos, 17: 61-71.

Gell, A. 1996. Art and Agency: An Anthropological Theory. Oxford: Oxford University Press.
Giddens, A. 1991. Modernity and Self-identity: Self and Society in the Late Modern Age. Stanford (CA): Stanford University Press.

Gifford-Gonzalez, D. 2008. Thoughts on a Method for Zooarchaeological Study of Quotidian Life. In: S. Montón-Subías \& M. Sánchez Romero, eds. Engendering Social Dynamics: The Archaeology of Maintenance Activities (BAR International Series 1862). Oxford: Archaeopress, pp. 15-23.

Gilchrist, R. 2008. Nurturing the Dead: Medieval Women as Family Undertakers. In: S. Montón-Subías \& M. Sánchez Romero, eds. Engendering Social Dynamics: The Archaeology of Maintenance Activities (BAR International Series 1862). Oxford: Archaeopress, pp. 41-47.

González Marcén, P. \& Picazo, M. 1997. El tiempo en arqueología. Madrid: Arco Libros.

González Marcén, P., Montón-Subías, S. \& Picazo, M. 2008. Towards an Archaeology of Maintenance Activities. In: S. MontónSubías \& M. Sánchez Romero, eds. Engendering Social Dynamics: The Archaeology of Maintenance Activities (BAR International Series 1862). Oxford: Archaeopress, pp. 3-8.

González-Ruibal, A. ed. 2013. Reclaiming Archaeology: Beyond the Tropes of Modernity. London: Routledge.

González-Ruibal, A. 2014. An Archaeology of Resistance: Materiality and Time in an African Borderland. Plymouth: Rowman \& Littlefield.

Goody, J. 2006. The Theft of History. Cambridge: Cambridge University Press.

Gosden, C. \& Lock, G. 1998. Prehistoric Histories. World Archaeology, 30: 2-12.

Gruzinski, S. 2012. L'aigle et le dragon. Démesure européenne et mondialisation au XVIe siècle. Paris: Fayard.

Hall, M. 1999. Subaltern Voices? Finding the Spaces between Things and Words. In: P. Funari, M. Hall \& S. Jones, eds. Historical Archaeology: Back from the Edge. London: Routledge, pp. 193-203.

Hastorf, C. 1991. Gender, Space, and Food in Prehistory. In: J. Gero \& M. Conkey, eds. Engendering Archaeology: Women and Prehistory. Oxford: Basil Blackwell, pp. 132-59.

Hendon, J. 1996. Archaeological Approaches to the Organisation of Domestic Labor: Household Practice and Domestic Relations. Annual Review of Anthropology, 25: 45-61. 
Hernández, G. 2012. Ceramics and the Spanish Conquest: Response and Continuity of Indigenous Pottery Technology in Central Mexico. Leiden \& Boston: Brill.

Hernando, A. 2002. Arqueología de la Identidad. Madrid: Akal.

Hernando, A. 2008. Why has History not Appreciated Maintenance Activities? In: S. Montón-Subías \& M. Sánchez Romero, eds. Engendering Social Dynamics: The Archaeology of Maintenance Activities (BAR International Series 1862). Oxford: Archaeopress, pp. 9-14.

Hernando, A. 2012a. La fantasía de la individualidad. Buenos Aires: Katz (English translation (2017) The Fantasy of Individuality: On the Sociobistorical Construction of the Modern Subject. New York: Springer).

Hernando, A. 2012b. Change, Individuality, and Reason: Or How Archaeology Has Legitimized a Patriarchal Modernity. In: A. González-Ruibal, ed. Reclaiming Archaeology: Beyond the Tropes of Modernity. London: Routledge, pp. 155-67.

Hughes, S.S. \& Hughes, B. 1997. Women in World History: Readings from 1500 to the Present. Armonk (NY): M.E. Sharpe.

Kant, I. 2013 (1784). An Answer to the Question: What Is Enlightenment? London: Penguin Books.

Kelly, K.G. 2003. The African Diaspora Starts Here: Historical Archaeology of Coastal West Africa. In: A.M. Reid \& P.J. Lane, eds. African Historical Archaeologies. New York: Springer, pp. 219-44.

Knapp, A.B. \& Meskell, L. 1997. Bodies of Evidence on Prehistoric Cyprus. Cambridge Archaeological Journal, 7: 183-204.

Knapp, A.B. \& Van Dommelen, P. 2008. Past Practices: Rethinking Individuals and Agents in Archaeology. Cambridge Archaeological Journal, 18: 15-34.

Lander, E. ed. 2000. La colonialidad del saber: eurocentrismo y ciencias sociales. Perspectivas lationoamericanas. Buenos Aires: CLASCO.

Leone, M. 1978. Time in American Archaeology. In: C. Redman, ed. Social Archaeology: Beyond Subsistence and Dating. London: Academic Press, pp. 25-36.

Leone, M. 2011. Making Historical Archaeology Postcolonial. In: T. Majewski \& D. Gaimster, eds. International Handbook of Historical Archaeology. New York: Springer, pp. 159-68.
Leone, M.P. \& Potter, P.B. 1988. Introduction: Issues in Historical Archaeology. In: M.P. Leone \& P.B. Potter, eds. The Recovery of Meaning. Washington: Smithsonian Institution Press, pp. 1-22.

Lightfoot, K.G. 1995. Culture Contact Studies: Redefining the Relationship between Prehistoric and Historical Archaeology. American Antiquity, 60: 199-217.

Lightfoot, K.G. 2015. Dynamics of Change in Multiethnic Societies: An Archaeological Perspective from Colonial North America. Proceedings of the National Academy of Sciences of the United States of America, 112: 9216-23.

Lightfoot, K.G., Martínez, A. \& Schiff, A.M. 1998. Daily Practice and Material Culture in Pluralistic Social Settings: An Archaeological Study of Culture Change and Persistence from Fort Ross, California. American Antiquity, 63: 199-222.

Little, B. 2007. Topical Convergence: Historical Archaeologists and Historians on Common Ground. Historical Archaeology, 41: 10-20.

Lloyd, G. 1984. The Man of Reason: 'Male' and 'Female' in Western Philosophy. Minneapolis (MN): University of Minnesota Press.

Lucas, G. 2005. The Archaeology of Time. London \& New York: Routledge.

Lugones, M. 2008. Colonialidad y género. Tabula rasa, 9: 73-101.

Machin, A. 2009. The Role of the Individual Agent in Acheulean Biface Variability. Journal of Social Archaeology, 9: 35-58.

Marks, R.B. 2002. The Origins of the Modern World: A Global and Ecological Narrative from the Fifteenth to the Twenty-first Century. Lanham (MD): Rowman \& Littlefield.

Meyers, C. 2008. Grinding to a Halt: Gender and the Changing Technology of Flour Production in Roman Galilee. In: S. Montón-Subías \& M. Sánchez Romero, eds. Engendering Social Dynamics: The Archaeology of Maintenance Activities (BAR International Series 1862). Oxford: Archaeopress, pp. 65-74.

Mignolo, W. 2008. La opción descolonial. Letral, 1: 4-22.

Millet, K. 1972. Sexual Politics. London: Abacus.

Mitchell, M.D. \& Scheiber, L.L. 2010. Crossing Divides: Archaeology as LongTerm History. In: L.L. Scheiber \& M.D. Mitchell, eds. Across a Great Divide: Continuity and Change in Native North 
American Societies, 1400-1900. Tucson (AZ): University of Arizona Press, pp. $1-22$.

Montón-Subías, S. 2010. Maintenance Activities and the Ethics of Care. In: L.H. Dommasnes, T. Hjørungdal, S. MontónSubías, M. Sánchez Romero \& N. Wicker, eds. Situating Gender in European Archaeologies. Budapest: Archaeolingua, pp. 23-33.

Montón-Subías, S. \& Abejez, L. 2015. ¿Qué es esa cosa llamada Arqueología Histórica? Complutum, 26: 11-35.

Montón-Subías, S. \& Lozano, S. 2012. La arqueología feminista en la normatividad académica. Complutum, 23: 163-76.

Montón-Subías, S., Bayman, J. \& Moragas, N. forthcoming. Arqueología del Colonialismo Español en Guam. In: B. Marín-Aguilera, ed. Repensar el colonialismo. Iberia, de colonial a potencia colonial. Madrid: JAS Arqueología.

Moore, H. 2000. Ethics and Ontology: Why Agents and Agency Matter. In: M.A. Dobres \& J.E. Robb, eds. Agency in Archaeology. London: Routledge, pp. 259-63.

Moral de Eusebio, E. 2016. Heterotopías en conflicto. Sexualidad, colonialismo y cultura material en las Islas Marianas durante el siglo XVII. In: I.P. Coelho, J. Torres, L. Serrão \& T. Ramos, eds. Entre ciência e cultura: Da interdisciplinaridade à transversalidade da arqueología (Actas das VIII Jornadas de Jovens em Investigação Arqueológica). Lisboa: CHAM, IEM, pp. 229-32.

Morris, C. 1987. The Discovery of the Individual: 1050-1200. Toronto: University of Toronto Press/Medieval Academy of America.

Munn, N.D. 1992. The Cultural Anthropology of Time: A Critical Essay. Annual Review of Anthropology, 21: 93-123.

Olivier, L. 2008. Le sombre abime du temps: mémoire et archéologie. Paris: Seuil.

Olivier, L. 2013. The Business of Archaeology is the Present. In: A. González-Ruibal, ed. Reclaiming Archaeology: Beyond the Tropes of Modernity. London: Routledge, pp. 117-29.

Orser, C. 1996. A Historical Archaeology of the Modern World. New York: Plenum.

Orser, C. 2012. An Archaeology of Eurocentrism. American Anthropologist, 77: 737-55.

Oyewumi, O. 1997. The Invention of Women: Making an African Sense of Western Gender
Discourses. Minneapolis (MN): University of Minnesota Press.

Panich, L.M. 2013. Archaeologies of Persistence: Reconsidering the Legacies of Colonialism in Native North America. American Antiquity, 78: 105-22.

Paredes, J. 2008. Una sociedad en estado y con estado despatriarcalizador. La Paz: Viceministerio de Asuntos Género y generacionales, Ministerio de Justicia.

Parker, C. 2010. Global Interactions in the Early Modern Age, 1400-1800. Cambridge: Cambridge University Press.

Picazo, M. 1997. Hearth and Home: The Timing of Maintenance Activities. In: J. Moore \& E. Scott, eds. Invisible People and Processes: Writing Gender and Childhood in European Archaeology. London \& New York: Leicester University Press, pp. 59-67.

Quijano, A. 1992. Colonialidad y Modernidad/ Racionalidad. Perú Indígena, 13: 11-20.

Quijano, A. 2000. Coloniality of Power, Eurocentrism, and Latin America. Nepantla: Views from South, 1: 533-80.

Quijano, A. \& Wallerstein, I. 1992. Americanity as a Concept, or the Americas in the Modern World-System. International Social Sciences Journal, 134: 549-57.

Rodríguez-Alegría, E. 2008. Narratives of Conquest, Colonialism, and Cutting-Edge Technology. American Anthropologist, 110: 33-43.

Rodríguez-Alegría, E. 2014. A Paradox in Colonialism and Technological Change. Revista de Arqueología Americana, 32: 7-26.

Sampson, E.E. 1988. The Debate on Individualism. Indigenous Psychologies of the Individual and their Role in Personal and Societal Functioning. American Psychologist, 43: 15-22.

Sánchez Romero, M. 2008. An Approach to Learning and Socialization in Children during the Spanish Bronze Age. In: L.H. Dommasnes \& M. Wrigglesworth, eds. Children Identity and the Past. Newcastle: Cambridge Scholars Publishing, pp. 113-24.

Sánchez Romero, M. \& Aranda, G. 2008. Changing Foodways: New Strategies in Food Preparation, Serving, and Consumption in the Bronze Age of the Iberian Peninsula. In: S. Montón-Subías \& M. Sánchez Romero, eds. Engendering Social Dynamics: The Archaeology of Maintenance Activities (BAR International Series 1862). Oxford: Archaeopress, pp. 83-94. 
Sedikides, C. \& Brewer, M.C. 2015. Individual Self, Relational Self, Collective Self. London: Routledge.

Segato, R. 2015. Género y colonialidad: del patriarcado comunitario de baja intensidad al patriarcado colonial moderno de alta intensidad. In: R. Segato, ed. La crítica de la colonialidad en ocho ensayos. Y una antropología por demanda. Buenos Aires: Prometeo, pp. 69-99.

Seidler, V. 1989. Rediscovering Masculinity: Reason, Language and Sexuality. London: Routledge.

Seidler, V. 1993. Unreasonable Men: Masculinity and Social Theory. London: Routledge.

Shanks, M. \& Tilley, C. 1987. Abstract and Substantial Time. Archaeological Review from Cambridge, 6: 32-41.

Silliman, S. 2005. Culture Contact or Colonialism? Challenges in the Archaeology of Native North America. American Antiquity, 70: 55-74.

Silliman, S. 2009. Change and Continuity, Practice and Memory: Native American Persistence in Colonial New England. American Antiquity, 74: 211-30.

Sökefeld, M. 1999. Debating Self, Identity, and Culture in Anthropology. Current Anthropology, 40: 417-47.

Spivak, G.C. 1988. Can the Subaltern Speak? In: C. Nelson \& L. Grossberg, eds. Marxism and the Interpretation of Culture. Basingstoke: Macmillan Education, pp. 271-313.

Stahl, A.B. 2012. When Does History Begin? Material Continuity and Change in West Africa. In: O.M. Hart \& L. Frink, eds. Decolonizing Indigenous Histories: Exploring Prehistoric/Colonial Transitions in Archaeology. Tucson (AZ): University of Arizona Press, pp. 158-77.

Suárez-Krabbe, J., Rodrigues, L.P., Lollike, H. \& Jensen, L.L. eds. 2009. Epistemologies of Transformations: The Latin American Decolonial Option and its Ramifications. Kult, 6, Special Issue.

Suzman, J. 2004. Hunting for Histories: Rethinking Historicity in the Western Kalahari. In: A. Barnard, ed. HunterGatherers in History, Archaeology and Anthropology. Oxford: Berg, pp. 201-16.

Tarble de Scaramelli, K., \& Scaramelli, F. 2012. Cooking for Fame or Fortune: The Effect of European Contact on Casabe Production in the Orinoco. In: S.R. Graff
\& E. Rodríguez-Alegría, eds. The Menial Art of Cooking: Archaeological Studies of Cooking and Food Preparation. Boulder (CO): University Press of Colorado, pp. 119-43.

Thomas, J. 2004. Archaeology and Modernity. London \& New York: Routledge.

Tringham, R. 1991. Household with Faces: The Challenge of Gender in Prehistoric Architectural Remains. In: J. Gero \& M. Conkey, eds. Engendering Archaeology: Women and Prehistory. Oxford: Basil Blackwell, pp. 93-131.

Verdesio, G. 2013. Indigeneity and Time: Towards a Decolonization of Archaeological Temporal Categories and Tools. In: A. González-Ruibal, ed. Reclaiming Archaeology: Beyond the Tropes of Modernity. London: Routledge, pp. 168-80.

Veyne, P. 1987. Histoire de la vie privée. Paris: Seuil.

Voss, B. 2008. Gender, Race and Labor in the Archaeology of the Spanish Colonial America. Current Antbropology, 4: 861-93.

Wallerstein, I. 1974. The Modern World-System. New York \& London: Academic Press.

Wallerstein, I. 2006. European Universalism: The Rhetoric of Power. New York: New Press.

Weintraub, K. 1978. The Value of the Individual: Self and Circumstance in Autobiography. Chicago (IL): University of Chicago Press.

Wolf, E.R. 1982. Europe and the People Without History. Berkeley (CA): University of California Press.

Wright, D., \& Ricardi, P. 2014. Both Sides of the Frontier: The 'Contact' Archaeology of Villages on Mabuyaq, Western Torres Strait. Quaternary International, 385: 10211. http://dx.doi.org/10.1016/j.quaint. 2014.09.028.

\section{Biographical Notes}

Sandra Montón-Subías is an ICREA Research Professor at Universitat Pompeu Fabra, Barcelona, Spain. Sandra has broad interests in social and theoretical archaeology. She is committed to a feminist archaeology, and to the understanding of gender and maintenance activities, both in 
the past and the present. Since October 2011, she has added the archaeology of Modern Spanish Colonialism and the First Globalization to her research interests, which also include the archaeology of the Bronze Age Mediterranean. Her recent publications include Archaeologies of Early Modern Spanish Colonialism (Springer, 2016), The Archaeology of Bronze Age Iberia (Routledge, 2014), Field Archaeology from around the World: Ideas and Approaches (Springer, 2015), “QQué es esa cosa llamada arqueología histórica?” (Complutum 26(1), 2015), and "European Gender Archaeologies in Historical Perspective" (European Journal of Archaeology 15(3), 2012).

Address: Departament d'Humanitats, Universitat Pompeu Fabra, 08005 Barcelona, Spain, and ICREA, Pg. Lluís Companys 23, 08010 Barcelona, Spain. [email: sandra.monton@upf.edu]
Almudena Hernando is Professor of Archaeology at the Department of Prehistory, and a member of the Institute of Feminist Research at the Universidad Complutense, Madrid, Spain. Her research focuses on the theoretical basis underlying identity construction in general, with special attention to oral societies and women. She has written several books and articles on this topic, such as Archaeology of Identity (Akal, 2002) and The Fantasy of Individuality: On the Construction of the Modern Subject (Springer, 2017). She has carried out fieldwork among the horticulturalists Q'eqchí (Guatemala), the hunter-gatherers Awá (Amazon, Brazil), and the hoe agriculturalists Gumuz and Dats'in (Ethiopia).

Address: Departamento de Prehistoria, Facultad de Geografía e Historia. Universidad Complutense, 28040 Madrid, Spain. [email: hernando@ghis.ucm.es]

\section{Colonialisme moderne, Eurocentrisme et archéologie historique : quelques propos relatifs à l'égalité des sexes}

Cet article contient certaines réflexions concernant les valeurs et principes appliqués par les archéologues quand ils parlent d'altérité. Nos réflexions s'inscrivent dans le contexte de l'archéologie du colonialisme moderne et réexaminent certains aspects relatifs à l'une des questions les plus brûlantes en archéologie des périodes historiques récentes: l'Eurocentrisme. Nous soutenons que pour combattre l'Eurocentrisme dans notre discipline il est nécessaire d'inclure non seulement les laissés pour compte en tant qu'agents mais encore de remettre en cause la logique sur la base de laquelle les récits du passé ont été construits. Nous examinons la notion que l'bistoire concerne l'étude des changements et abordons la continuité sociale d'un point de vue féministe. Nous notons que certaines descriptions de situations coloniales peuvent, même sans le vouloir, projeter une perspective qui repose sur une manière de voir les choses masculine et occidentale quand il s'agit d'expliquer les dynamiques sociales et personnelles, ce qui mène à estomper la diversité ontologique et renforcer involontairement un Eurocentrisme que nous cherchons à éviter. Translation by Madeleine Hummler

Mots-clés: archéologie des périodes historiques récentes, colonialisme moderne, Eurocentrisme, archéologie féministe, changement et continuité, activités de maintien 


\section{Moderner Kolonialismus, Eurozentrismus und historische Archäologie: einige Überlegungen über Geschlecht}

In diesem Artikel möchten wir einige Überlegungen über die Werte und Grundsätze, welche die Andersartigkeit in der Archäologie beschreiben, vorlegen. Wir stellen unsere Gedanken in Zusammenhang mit der Archäologie des modernen Kolonialismus und erwägen erneut einige Aspekte, die eine der strittigsten Fragen in der historischen Archäologie betreffen: der Eurozentrismus. Um den Eurozentrismus in unserem Fach zu bekämpfen, sind wir der Meinung, dass wir nicht nur die Entrechteten als neue Agenten in Betracht ziehen müssen, sondern auch, dass wir die grundsätzliche Logik, welche die Darstellungen der Vergangenheit geprägt hat, infrage stellen müssen. Wir legen den Schwerpunkt auf die Auffassung der Geschichte, welche den Wechsel bevorzugt, und auf die soziale Kontinuität aus einer feministischen Perspektive. Wir machen darauf aufmerksam, dass einige Darstellungen von kolonialen Situationen, auch wenn das nicht die Absicht war, eine vorherrschende, männliche und westliche Art zu sein, fördern können. Dieser Denkweise begegnet man in Erklärungen von sozialen und persönlichen Umständen, was die ontologische Diversität unscharf macht und unabsichtlich den Eurozentrismus, den wir vermeiden wollen, verstärkt. Translation by Madeleine Hummler

Stichworte: historische Archäologie, moderner Kolonialismus, Eurozentrismus, feministische Archäologie, Wechsel und Kontinuität, Unterhaltstätigkeiten 